\title{
Thermodynamic Performance Evaluation of a Geothermal Drying System
}

\author{
Hüseyin Utku Helvacı and Gülden Gökçen Akkurt
}

\begin{abstract}
Renewable energy sources such as geothermal energy can be used in drying processes as a heat source due to the high energy costs of fossil fuels.

In this study, geothermal cabinet type dryer was constructed and situated in Balcova-Narlidere Geothermal Field, Turkey where the clean city water of district heating system is used as an energy source for the dryer. The dryer was tested on site for drying of olive leaves and energy and exergy analyses of the drying process conducted under two cases: Case 1. Exhaust air was rejected to the environment. Case 2. A portion of exhaust air was re-circulated. Energy Utilization Ratio (EUR) was determined as 7.96 for Case 1 and 50.36 for Case 2. The highest rate of exergy destruction occurred in the fan, followed by heat exchanger and the dryer, accounting for $0.2913,0.05663$ and $0.0115 \mathrm{~kW}$, respectively. Exergetic efficiency of the drying chamber was calculated as $89.66 \%$. Re-circulating the exhaust air decreased the exergy value at the outlet of the dryer from 0.1013 to $0.08104 \mathrm{~kW}$, indicating that re-using the air increases the performance of the dyer.
\end{abstract}

\section{Keywords}

Drying • Geothermal energy • Olive leaves • Energy analysis • Exergy analysis

\section{Introduction}

Herbal, medicinal and aromatic plants have been widely used for preventing and treating specific ailments and diseases, which provide the raw material for the food, cosmetic and pharmaceutical industries to produce spice, essential oils and drugs [1]. Olive leaves have beneficial effects on human metabolism such as combating fevers and other diseases which are attributed to the phenolic compounds structure [2,3]. Drying of olive leaves is the most important process prior to consumption and extraction by reducing moisture content and avoiding the interference of water to the process [4, 5]. Although conventional drying methods such as open air sun drying are still the most common method in the world, it is not suitable for drying of herbs and spices due to contamination with dust, soil and insects. Furthermore, unmanageable drying parameters such as temperature and velocity cause over-drying results in loss of quality of dried product. Therefore, the drying process should be undertaken in closed and controlled environment such as hot air dying in a tunnel or cabinet dryer. An improvement in the quality of dried product and decrease in time necessitates better technical drying process which results in a huge amount of thermal and electrical energy use. Thus, the use of renewable energy sources such as solar and

H.U. Helvacı $(\bowtie) \cdot$ G.G. Akkurt

Energy Engineering Programme, Izmir Institute of Technology, 35430 Gulbahce Koyu, Urla-Izmir, Turkey

e-mail: huseyinhelvaci@iyte.edu.tr; guldengokcen@iyte.edu.tr 
geothermal energy plays an important role in the utilization of controlled conventional drying methods [6]. The daily and seasonal changes of solar intensity in limited time that sun light is available during the day make the solar drying process intermittent. On the other hand, geothermal fluids flow at constant flowrate throughout the year which are considered as continuous resources. In drying applications, geothermal fluids can be used indirectly by a heat exchanger or heat pumps.

Numerous studies were conducted on drying where the geothermal energy was used as a heat source of the dryer. Andiritsos et al. [7] investigated a tomato drying system in Greece where the geothermal fluid enters the water-air heat exchanger to heat the drying air. Also, they discussed the possibilities of using geothermal energy for drying traditional agricultural products in the Aegean Islands. As a result of this study, such a geothermal drying unit seemed to be quite flexible regarding the product to be dried and low-temperature geothermal resources can be used efficiently to dry many agricultural products. Kumoro and Kristano [8] conducted a research on drying of tobacco leaves using geothermal steam and the effect of the steam velocity on the drying rate of tobacco leaves. Results showed that the increase of steam flow rate can improve the drying performance. Hirunlabh et al. [9] designed an industrial dryer and obtained the appropriate drying conditions and conducted cost analysis using geothermal hot water from the geothermal power plant in Thailand. Sumotarto [10] investigated a simulation study of beans and grains drying by a geothermal dryer which would be implemented and technically feasible in Kamojang geothermal field, Indonesia.

Thermodynamic analysis, mainly exergy analysis, plays an important role for system design, analysis and optimization of thermal systems [11]. Since the maximum moisture removal for desired final conditions of dried product is the main objective with the use of minimum amount of energy in drying industry, both quantity and quality of energy should be considered throughout the drying process. In other words, energy and exergy analysis of drying system should be conducted by using the first and second laws of thermodynamics [12]. Although several studies have been conducted on energy and exergy analysis of solar drying systems [13-15] very few studies have been undertaken on energy and exergy analysis of geothermal ones which were based on the geothermal heat pump drying [16, 17].

In this study, a cabinet type geothermal drier where geothermal fluid is introduced indirectly by a heat exchanger was constructed and situated in Balcova-Narlidere Geothermal Field (BNGF), Turkey. Temperature, relative humidity and velocity data of dried air are measured and evaluated the performance of the geothermal drying system by energy and exergy analysis.

\section{Balcova-Narlidere Geothermal Field}

BNGF is located $7 \mathrm{~km}$ west from the Izmir City Centre and $1 \mathrm{~km}$ south from the Izmir-Cesme highway. The Field feeds the largest district heating application in Turkey with a heating capacity of $159 \mathrm{MW}_{\mathrm{t}}$, including $2,470,000 \mathrm{~m}^{2}$ heating capacity and 15,660 subscribers. The system is operated by 14 heat centres and two pump stations. The geothermal fluid gathered from the 13 production wells first mixed in the mixing chamber in order to bring the temperature of mixture from $120^{\circ} \mathrm{C}$ down to $99^{\circ} \mathrm{C}$. Then, the fluid is transmitted to the heat exchangers where the heat is transferred to the clean city water [18]. Figure 29.1 provides a schematic diagram for the Balcova-Narlidere District Heating System (BNDHS) (Celen Ender, May 6, 2012, personal communication).

The dryer was placed in Yenikale Heat Centre which is one of the heat centres of BNDHS. A schematic diagram of the Yenikale Heat Centre and the connection of the dryer to the circulation water line were shown in Fig. 29.2. Heat centres are the stations where geothermal fluid (1) transfers its heat by primary plate type heat exchangers (3), to the clean city water (4) which circulates through the city and provides heat to the buildings. In Yenikale Heat Centre, the clean city water returns to the heat exchanger (5) at a temperature of $62-65{ }^{\circ} \mathrm{C}$ where the dryer heat input is supplied (6). Since geothermal fluid temperature in the field $\left(120^{\circ} \mathrm{C}\right)$ is much higher than the temperatures for the dryer $\left(40-60{ }^{\circ} \mathrm{C}\right)$, circulation water from district heating system was decided to be used. 


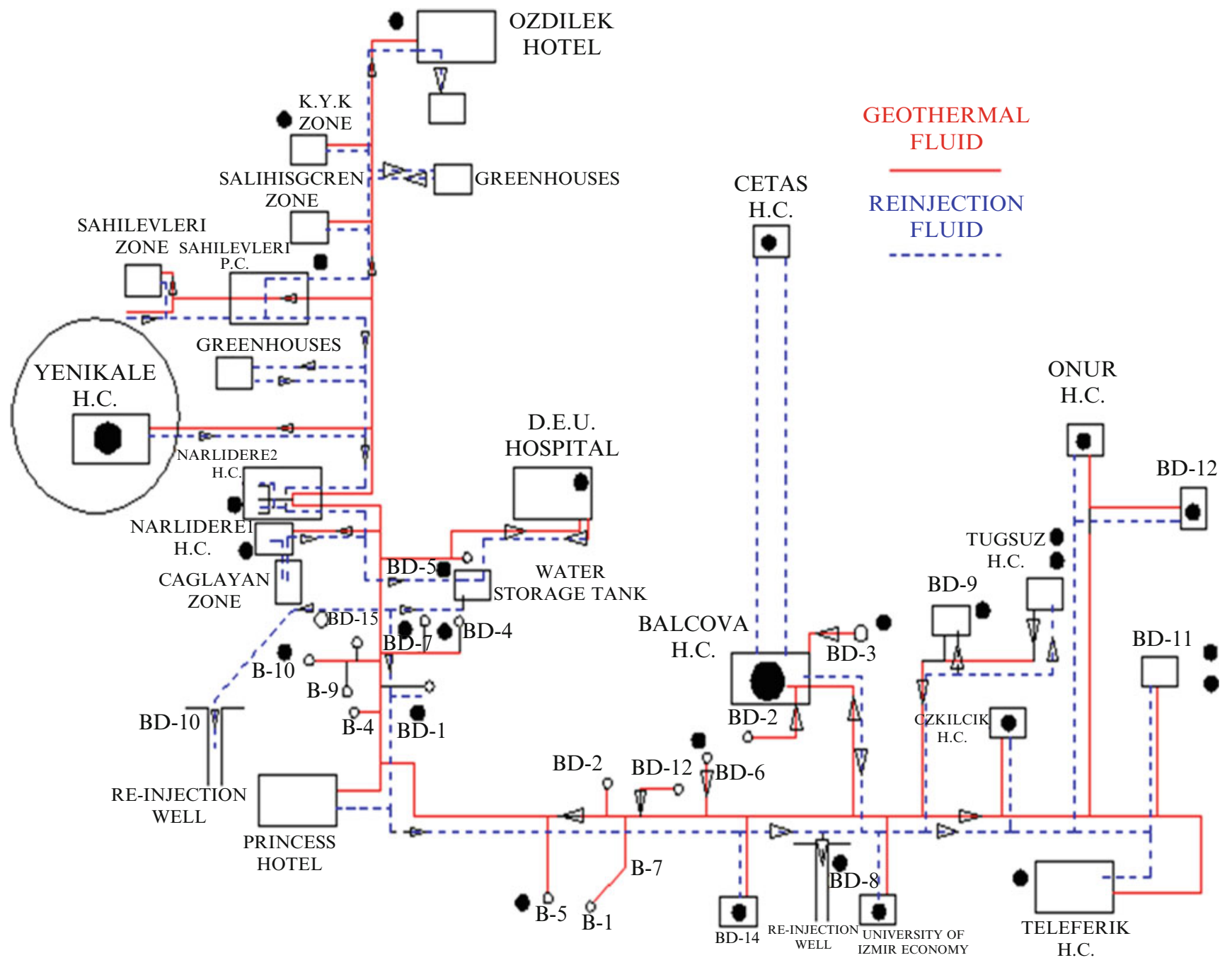

Fig. 29.1 A schematic diagram of Balcova-Narlidere geothermal district heating system (Celen Ender, May 6, 2012, personal communication)

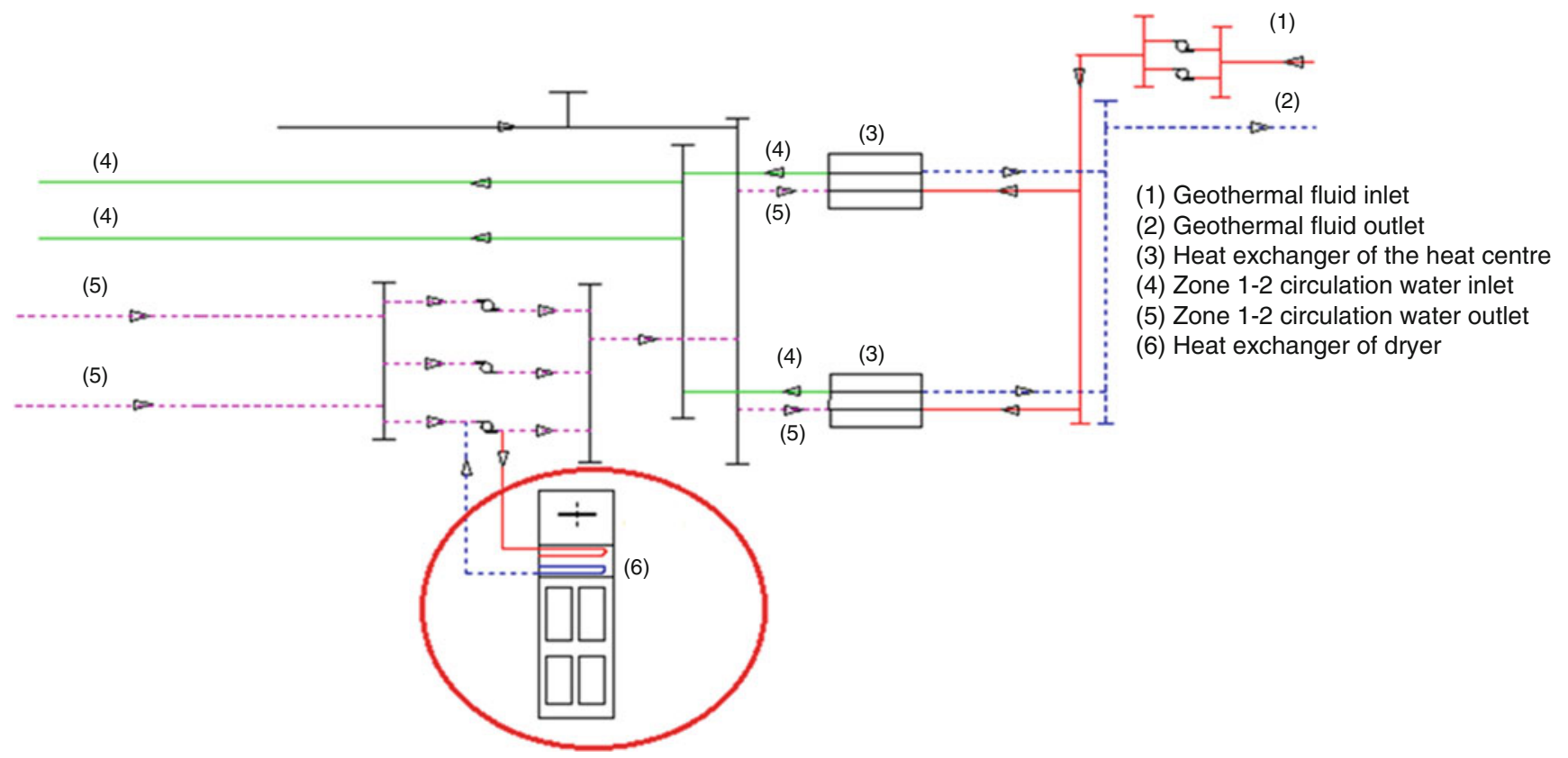

Fig. 29.2 A location of the geothermal dryer in Yenikale Heat Centre 


\section{Materials and Methods}

The geothermal dryer (Figs. 29.3 and 29.4) is a cabinet type dryer, consists of three sections; fan unit, heating unit and drying tunnel sections. A schematic diagram of the dryer was given in Fig. 29.5.

As seen in Fig. 29.5, drying air is regulated by a centrifugal fan (1) which draws the fresh air into the dryer. The fresh air either is mixed with re-circulated air or directly enters to the water-to-air heat exchanger (2). The heated air leaving the water-to-air heat exchanger reaches the drying chamber (4) which was made of approximately $1^{\prime \prime}$ plywood. The inner surface of the dryer was insulated by fibre glass and covered with an aluminium sheet in order to reduce heat losses. The dryer contains six trays (3) which are $600 \mathrm{~mm}$ in length and $500 \mathrm{~mm}$ in width, and there is an air re-circulating unit (5) to recover the exhaust air (Fig. 29.4). The clean water returning to the primary heat exchanger in Yenikale Heat Center is directed to the heat exchanger of the drier (Fig. 29.2) as a heat source. During the experiments, temperature [ambient (12), tray inlet (10), tray exit (11)], relative humidity [ambient (12), tray inlet (10), tray exit (11)] and velocity [tray inlet (9)] of drying air were measured and recorded by a datalogger.

Drying experiments were conducted in April, 2012 with Olive leaves (Oleaeuropaea L.) which were collected from the olive trees in the Izmir Institute of Technology Campus Area, Urla-Izmir-Turkey. The olive leaves were stored for 3 days in the air proof plastic bags at $4{ }^{\circ} \mathrm{C}$, then were spread onto the trays as a thin layer. Approximately a mass of $150 \mathrm{~g}$ fresh olive

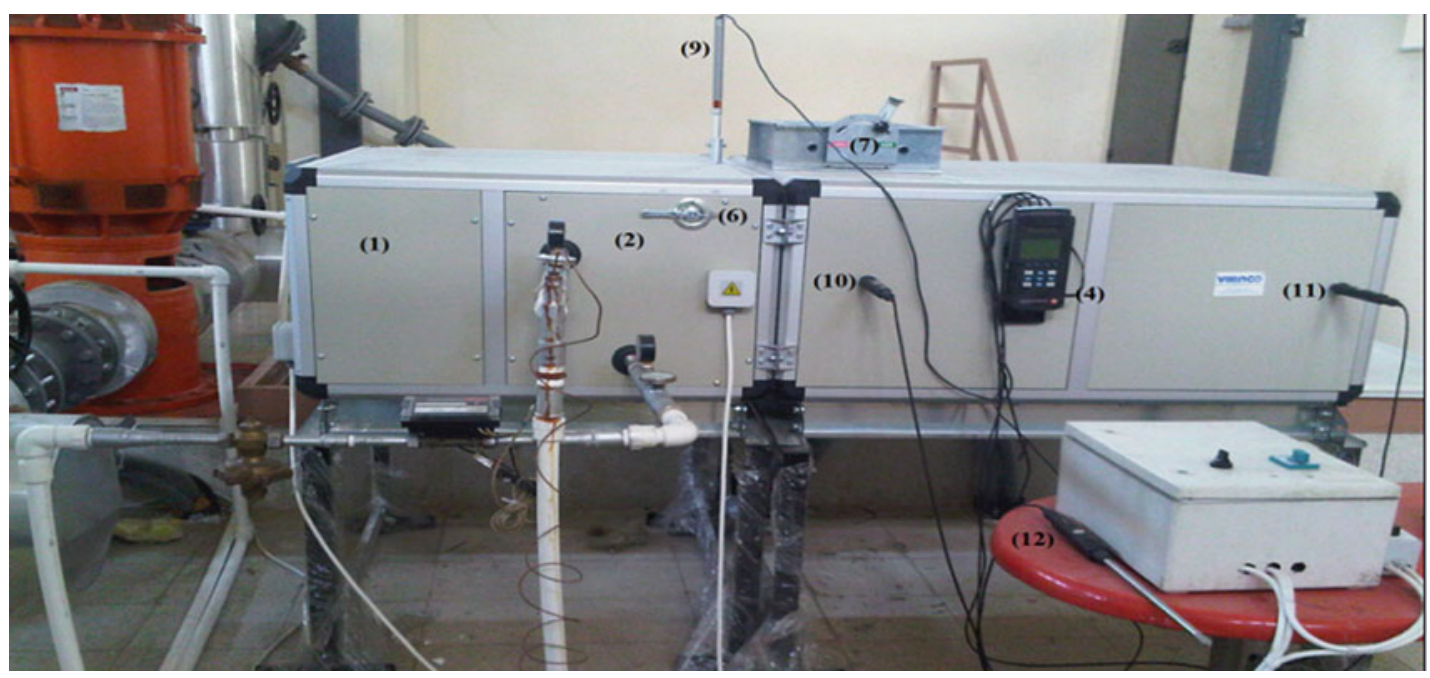

Fig. 29.3 A view of geothermal dryer

Fig. 29.4 A view of drying trays

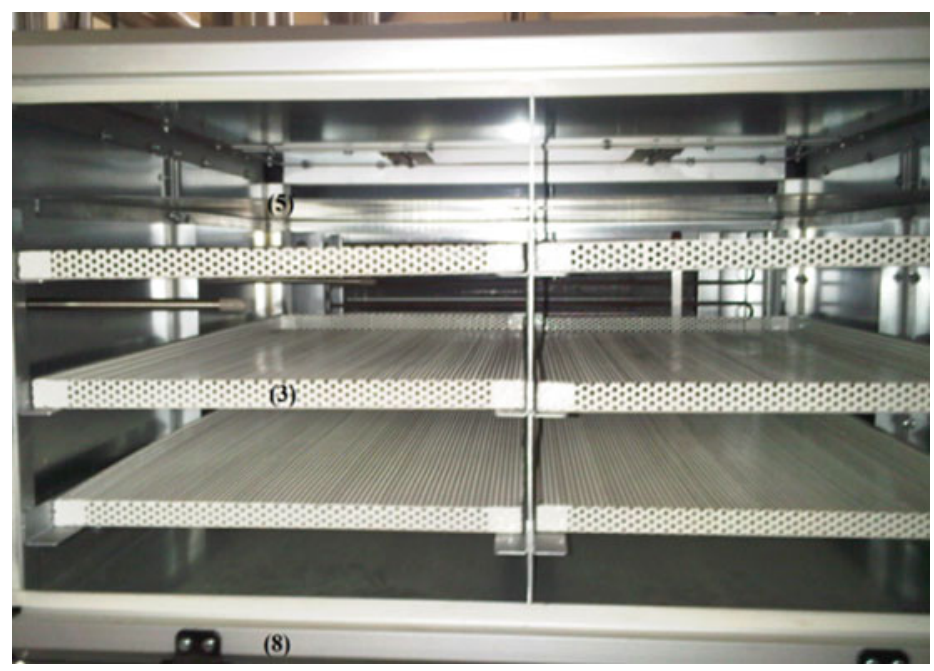






(1) Fan, (2) Heat exchanger, (3) Trays, (4) Drying chamber, (5) Recirculation unit, (6) Discharger flap

(7) Chimney, (8) Door, (9) Velocity anemometer, (10) - (11) - (12) Thermocouples

Fig. 29.5 Schematic diagram of the geothermal dryer

leaves was used for each drying experiment. The leaves were dried until the drying rate reached zero when the moisture content of the leaves was about 4-6\% (w-b). To determine the change in weight, a digital weighing apparatus $( \pm 0.01 \mathrm{~g})$ was used during the experiments.

\section{Analysis}

Using the measured temperature, relative humidity and velocity data at tray inlet, outlet and the environment, energy and exergy analysis were conducted for two cases:

- Case 1: without air re-circulation

- Case 2: with air re-circulation

\section{Energy Analysis}

Drying process was considered as a steady-state, steady-flow process in the analysis of mass (air, water) and energy balance (Figs. 29.6 and 29.7). General equations of mass conservation of drying air for drying chamber and mass conservation of moisture are given in Eqs. (29.1) and (29.2).

$$
\begin{gathered}
\dot{m}_{d a, e n v}=\dot{m}_{a i r,(1)} \\
\dot{m}_{d a, e n v} \times h_{d a, e n v}=\dot{m}_{a i r,(1)} \times h_{a i r,(1)}
\end{gathered}
$$

Equations (29.3)-(29.5) are applied to compute the mass and energy balance [15, 19].

$$
\begin{gathered}
\dot{m}_{d a}=\dot{m}_{d a, e n v}+\dot{m}_{r e, a i r} \\
\dot{m}_{d a, e n v} \times(1-r)+\dot{m}_{r e c, a i r} \times(r)=\dot{m}_{\text {air },(1)} \\
\dot{m}_{d a, e n v} \times h_{d a, e n v} \times(1-r)+\dot{m}_{r e, a i r} \times h_{r e, a i r} \times(r)=\dot{m}_{\text {air },(1)} \times h_{\text {air },(1)}
\end{gathered}
$$

Mass and energy balance equations are applied to each component of the dryer.

\section{Fan}

Equations (29.6)-(29.8) was used to compute mass and energy balance for the fan.

$$
\dot{m}_{a i r,(1)}=\dot{m}_{a i r,(2)}=\dot{m}_{d a}
$$


Fig. 29.6 Schematic illustration of drying system (without air re-circulation)

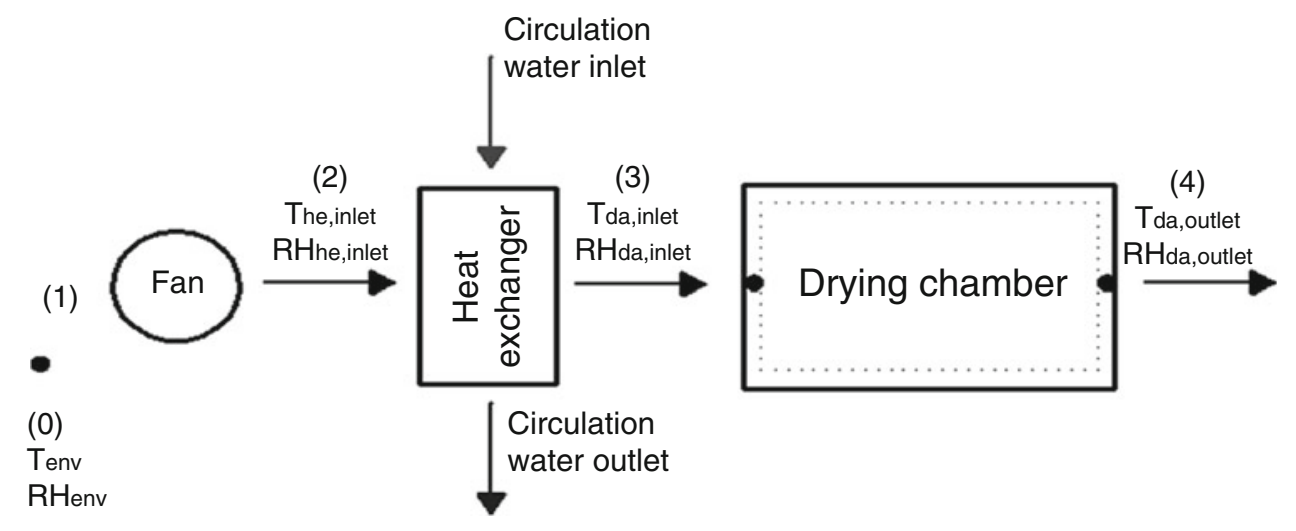

Fig. 29.7 Schematic illustration of drying system (with air re-circulation)

\section{Heat Exchanger}

For the water site of the heat exchanger Eqs. (29.9) and (29.10), for the air site of the heat exchanger Eqs. (29.11) and (29.12) were applied.

(a) Water

$$
\begin{gathered}
\dot{m}_{\text {water }, \text { in }}=\dot{m}_{\text {water }, \text { out }} \\
\dot{Q}_{\text {water }, \text { in }}=\dot{m}_{\text {water }} \times\left(h_{\text {water }, \text { in }}-h_{\text {water }, \text { out }}\right)
\end{gathered}
$$

(b) Air

$$
\begin{gathered}
\dot{m}_{a i r,(2)}=\dot{m}_{a i r,(3)}=\dot{m}_{d a} \\
\dot{Q}_{a i r}=\dot{m}_{d a} \times\left(h_{3}-h_{2}\right)
\end{gathered}
$$




\section{Drying Chamber}

$$
\sum \dot{m}_{d a,(3)}=\sum \dot{m}_{d a,(4)}=\dot{m}_{d a}
$$

General equation of mass balance of moisture can be expressed as

$$
\sum\left(\dot{m}_{\text {water }}\right)_{\text {in }}+\left(\dot{m}_{\text {water }}\right)_{\text {product }}=\sum\left(\dot{m}_{\text {water }}\right)_{\text {out }}
$$

or

$$
\sum\left(\omega_{d a}\right)_{i n} \times \dot{m}_{d a,(3)}+\left(\dot{m}_{\text {water }}\right)_{\text {product }}=\sum\left(\omega_{d a}\right)_{\text {out }} \times \dot{m}_{d a,(4)}
$$

Equation (29.15) is used to transform the relative humidity to humidity ratio of the air at inlet and outlet of the drying chamber.

$$
\omega=0.622 \times \frac{R H P \text { sat } @ T}{P-\text { Psat } @ T}
$$

Total mass flow of air required for drying process was calculated by Eq. (29.16).

$$
\dot{m}_{d a}=\rho_{d a} \times V_{d a} \times A
$$

The enthalpy of drying air was obtained by Eq. (29.17).

$$
h=\left(C_{p}\right)_{d a} T_{d a}+w \cdot h_{s a t @ T}
$$

The energy utilization (EU) which can be expressed as the amount of energy employed during moisture removal of the product was calculated using Eq. (29.18).

$$
E U=\dot{m}_{d a} \cdot\left[h_{d a,(3)}-h_{d a,(4)}\right]
$$

The energy utilization ratio (EUR) was defined as the ratio of the energy utilization to the energy given from the heat exchangers of dryer [Eq. (29.19)].

$$
E U R=\frac{\dot{\mathrm{m}}_{d a}\left(h_{d a, 3}-h_{d a, 4}\right)}{\dot{\mathrm{m}}_{d a}\left(h_{3}-h_{2}\right)} \times 100
$$

\section{Exergy Analysis}

Total exergy of inlet, outlet and losses through the system components were determined in the scope of the second law analysis of thermodynamics [12,19]. The exergy values are calculated by using the characteristics of the working fluid from an energy balance [20].

The specific exergy can be determined by Eq. (29.20).

$$
\psi=\left(h-h_{0}\right)-T_{0} \times\left(s-s_{0}\right)
$$

Exergy rate is stated by Eq. (29.21).

$$
\dot{E x}=m \psi
$$

or

$$
\dot{E} x=\dot{m}_{d a} C_{p d a}\left[\left(T-T_{0}\right)-T_{0} \ln \frac{T}{T_{0}}\right]
$$

The dead state temperature $\left(\mathrm{T}_{0}\right)$ was taken as the measured environment temperature $\left(\mathrm{T}_{\text {env }}\right)$. Exergy destructions as well as exergetic efficiencies were obtained by exergy balances for each component [Eqs. (29.22), (29.24), (29.25), and (29.27)]. 
Exergetic efficiency can be defined as the ratio of exergy loss (exergy inflow-exergy outflow) to exergy inflow to the drying chamber. Equations (29.23), (29.26) and (29.28) were applied to determine exergetic efficiencies of each component.

Fan

$$
\begin{gathered}
E^{\prime} x_{d e s t, f a n}=\dot{W}_{f a n}+\dot{m}_{d a} \times\left(\psi_{2}-\psi_{1}\right) \\
\varepsilon_{f a n}=\frac{\dot{m}_{d a} \times\left(\psi_{2}-\psi_{1}\right)}{\dot{W}_{f a n}}
\end{gathered}
$$

\section{Heat Exchanger}

(a) Water

$$
E^{\prime} x_{\text {dest }, \text { water }}=\dot{m}_{\text {water }} \times\left(\psi_{\text {water, in }}-\psi_{\text {water, out }}\right)
$$

(b) Air

$$
\begin{gathered}
E^{\prime} x_{d e s t, a i r}=\dot{m}_{d a} \times\left(\psi_{3}-\psi_{2}\right) \\
\varepsilon_{h e}=\frac{\dot{m}_{d a} \times\left(\psi_{3}-\psi_{2}\right)}{\dot{m}_{\text {water }, \text { in }} \times\left(\psi_{\text {water, }, \text { in }}-\psi_{\text {water, out }}\right)}
\end{gathered}
$$

\section{Drying Chamber}

$$
\begin{gathered}
E^{\prime} x_{d e s t, d c}=\dot{m}_{d a} \times\left(\psi_{3}-\psi_{4}\right) \\
\varepsilon_{d c}=\frac{(\text { Exergy in }- \text { Exergy out })}{\text { Exergy in }}
\end{gathered}
$$

or

$$
\varepsilon_{d c}=1-\frac{\dot{m}_{d a} \times\left(\psi_{3}-\psi_{4}\right)}{\dot{m}_{d a} \times \psi_{3}}
$$

The following assumptions were made for the analysis:

- All the process was taken as a steady-state and steady-flow.

- Heat transfer to the system and work transfer from the system are positive.

- Potential and kinetic energy effects were neglected.

- Air is an ideal gas with constant specific heat.

\section{Results and Discussion}

Energy and exergy analysis of the dryer was conducted using measured temperature, velocity and relative humidity data (Table 29.1). Mass flow rates, enthalpy values and temperature of the air at inlet of the heat exchanger and energy and exergy rates were calculated using measured data and listed in Table 29.1. The reference-dead state conditions were determined as $\mathrm{T}_{0}=\mathrm{T}_{\text {env }}, \mathrm{RH}_{0}=\mathrm{RH}_{\mathrm{env}}, \mathrm{P}_{0}=101.325 \mathrm{kPa}$. The thermodynamic properties of air and water were obtained by using Engineering Equation Solver [21] software.

Table 29.2 presents exergy destruction and exergetic efficiencies for each component of the drying system, and EU and EUR of the drier are presented in Table 29.2. 
Table 29.1 Energy and exergy analysis data

\begin{tabular}{|c|c|c|c|c|c|c|c|c|c|}
\hline State no & Fluid & $\mathrm{T}\left({ }^{\circ} \mathrm{C}\right)$ & $\mathrm{RH}(\%)$ & $\mathrm{h}(\mathrm{kJ} / \mathrm{kg})$ & $\mathrm{s}(\mathrm{kJ} / \mathrm{kg} \mathrm{K})$ & $\dot{\mathrm{m}}(\mathrm{kg} / \mathrm{s})$ & $\begin{array}{l}\text { Specific } \\
\text { exergy }(\mathrm{kJ} / \mathrm{kg})\end{array}$ & $\begin{array}{l}\text { Exergy } \\
\text { rate }(\mathrm{kW})\end{array}$ & $\begin{array}{l}\text { Energy } \\
\text { rate }(\mathrm{kW})\end{array}$ \\
\hline 0 & Air/dead state & 22 & 42 & 39.67 & 5.75 & - & - & - & - \\
\hline 1 & Air/fan inlet & 37 & 19.4 & 56.79 & 5.8 & 0.20 & 0.3175 & 0.066 & 11.8 \\
\hline 2 & Air/fan outlet-HE inlet & 37.9 & 18.5 & 57.67 & 5.81 & 0.20 & 0.3615 & 0.076 & 11.97 \\
\hline 3 & Air/HE outlet-dryer inlet & 40.9 & 15.7 & 60.81 & 5.82 & 0.21 & 0.538 & 0.1128 & 12.78 \\
\hline 4 & Air/dryeroutlet & 39.8 & 16.4 & 59.23 & 5.815 & 0.21 & 0.4823 & 0.1013 & 12.43 \\
\hline $\mathrm{W}_{\text {in }}$ & Water/HE inlet & 62 & - & 259.6 & 0.8562 & 0.03 & 63.11 & 2.272 & 9.34 \\
\hline $\mathrm{W}_{\text {out }}$ & Water/HE outlet & 56.5 & - & 236.5 & 0.7866 & 0.03 & 60.51 & 2.178 & 8.52 \\
\hline
\end{tabular}

Table 29.2 Exergy destruction, exergetic efficiency, EU and EUR data of the dryer

\begin{tabular}{llc}
\hline Component & Rate of exergy destruction, $\operatorname{Ex}_{\text {destruction }}(\mathrm{kW})$ & Exergetic efficiency, $\varepsilon(\%)$ \\
\hline Fan & 0.2913 & 3.08 \\
\hline Heat exchanger & 0.05663 & 39.52 \\
\hline Dryer & 0.0115 & 89.66 \\
EU $=0.3316 \mathrm{~kW}$ & \\
EUR $($ Case 1$)=7.96 \%$ & \\
EUR (Case 2) $=50.36 \%$ &
\end{tabular}

Fig. 29.8 The EUR values obtained from the experiments. (a) Case 1, (b) Case 2
Fig. 29.9 Exergy destruction values for each component of the drying system a

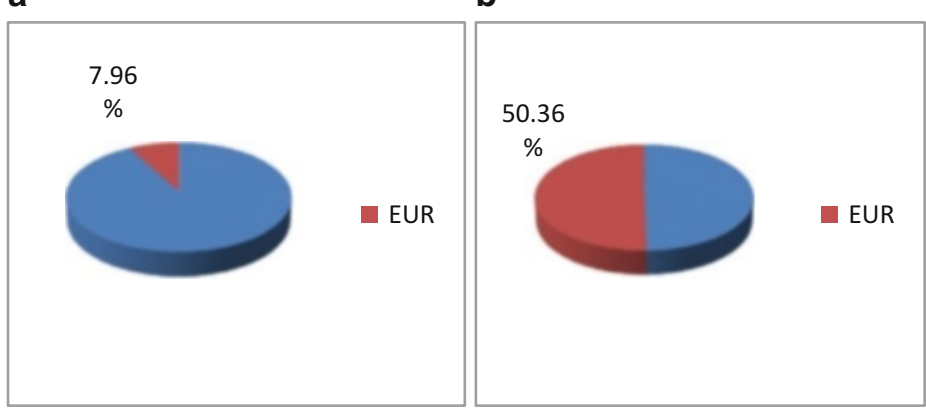

\section{b}

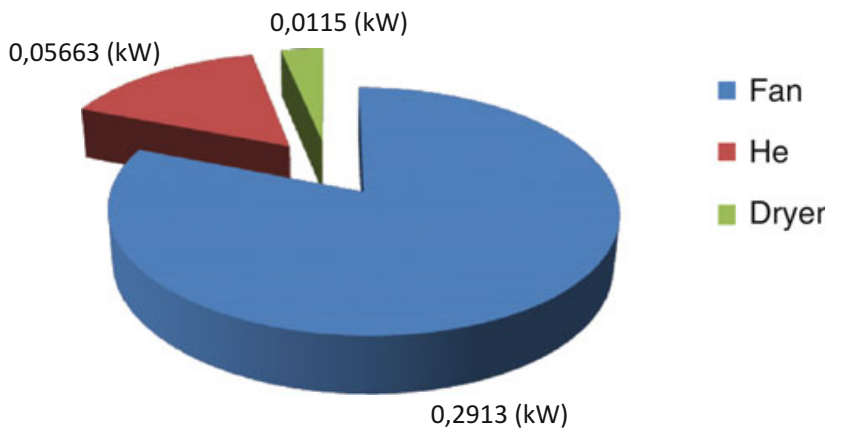

The EU, which indicates the amount of energy employed for the reduction of moisture content of the product, was calculated as $0.3316 \mathrm{~kW}$. EUR values were obtained as 7.96 and $50.36 \%$ for both Case 1 and Case 2, respectively. The EUR indicates the ratio of the energy utilization to the amount of energy given from the heat exchangers of the dryer. The lower EUR values obtained from the experiments that air was not circulated compared to the experiments with air re-circulation (Fig. 29.8). This indicates that re-cycling the exhaust air allows us to recover the energy leaving the dryer which decreases the energy input from the heat exchanger and increases the energy efficiency [22].

It is clear from Fig. 29.9 that the highest rate of exergy destruction occurs in the fan, followed by heat exchanger and the dryer, accounting for $0.2913,0.05663,0.0115 \mathrm{~kW}$, respectively. Exergetic efficiency of the drying chamber was calculated as $89.66 \%$ which is in a good agreement with the literature [22,23]. According to the results, exergy value at the outlet of the dryer was decreased from 0.1013 to $0.08104 \mathrm{~kW}$ by re-circulating the exhaust air which still has availability. 


\section{Conclusions}

Thermodynamic analysis of geothermal drying process of olive leaves in a cabinet type drier, where geothermal fluid was used indirectly by a heat exchanger, was performed in this study. The results of the energy and exergy analysis indicated that the greatest exergy destruction occurred in the fan, followed by the heat exchanger and the dryer. The re-circulation of the exhaust air increased EUR values from 7.96 to $50.36 \%$ and decreased the exergy at the outlet of the dryer by $0.02026 \mathrm{~kW}$, indicating that re-using the air enables us to increase the performance of the dryer. Besides the thermodynamic analysis, an economic analysis should be conducted to exhibit the viability of the re-circulation for commercial drying facilities.

Acknowledgement The authors would like to thank Izmir Jeotermal Inc. for their technical support.

\section{Nomenclature}

$\begin{array}{ll}\mathrm{A} & \text { Area }\left(\mathrm{m}^{2}\right) \\ \mathrm{C}_{\mathrm{p}} & \text { Specific heat }(\mathrm{kJ} / \mathrm{kg} \mathrm{K}) \\ \mathrm{EU} & \text { Energy utilization }(\mathrm{kW}) \\ \mathrm{EUR} & \text { Energy utilization ratio }(\%) \\ E^{\prime} x & \text { Exergy rate }(\mathrm{kW}) \\ \mathrm{h} & \text { Specific enthalpy }(\mathrm{kJ} / \mathrm{kg}) \\ \dot{m} & \text { Mass flow rate }(\mathrm{kg} / \mathrm{s}) \\ \mathrm{P} & \text { Pressure }(\mathrm{kPa})\end{array}$

Greek Letters

$\psi \quad$ Specific exergy $(\mathrm{kJ} / \mathrm{kg})$

$\varepsilon \quad$ Exergetic efficiency (\%)

\section{Subscripts}

$\begin{array}{ll}\text { da } & \text { Drying air } \\ \text { dc } & \text { Drying chamber } \\ \text { des } & \text { Destroyed } \\ \text { env } & \text { Environment } \\ \mathrm{He} & \text { Heat exchanger }\end{array}$

\section{Superscript}

0 Dead (reference) state

$\begin{array}{ll}\dot{Q} & \text { Heat rate }(\mathrm{kW}) \\ \mathrm{RH} & \text { Relative humidity }(\%) \\ \mathrm{r} & \text { Re-circulation ratio }(\%) \\ \mathrm{s} & \text { Specific entropy }(\mathrm{kJ} / \mathrm{kg} \mathrm{K}) \\ \mathrm{T} & \text { Temperature }\left({ }^{\circ} \mathrm{C}\right) \\ \mathrm{V} & \text { Velocity }(\mathrm{m} / \mathrm{s}) \\ \dot{W} & \text { Work rate }(\mathrm{kW}) \\ \rho & \text { Density }\left(\mathrm{kg} / \mathrm{m}^{3}\right)\end{array}$

$\omega \quad$ Specific humidity ratio ( $\mathrm{kg}$ water/kg air)

$\begin{array}{ll}\text { in } & \text { Inlet, inflow } \\ \text { out } & \text { Outlet, outflow } \\ \text { re } & \text { Re-circulated } \\ \text { sat } & \text { Saturated }\end{array}$

\section{References}

1. Oztekin S, Başçetinçelik A, Soysal Y (1999) Crop drying programme in Turkey. Renew Energy 1:789-794

2. Benavente-García O, Castillo J, Lorente J, Ortuño A, Del Rio JA (2000) Antioxidant activity of phenolics extracted from Oleaeuropaea L. leaves. Food Chem 68 (4):457-462

3. Bouaziz M, Sayadi S (2005) Isolation and evaluation of antioxidants from leaves of a Tunisian cultivar olive tree. Eur J Lipid Sci Technol 107(7-8):497-504

4. Bahloul N, Boudhrioua N, Kouhila M, Kechaou N (2009) Convective solar drying of olive leaves. J Food Process Eng 34(4):1338-1362

5. Soysal Y, Öztekin S (2001) PH—Postharvest Technology: technical and economic performance of a tray dryer for medicinal and aromatic plants. J Agric Eng Res 79(1):73-79

6. Fargali HM, Nafeh AA, Fahmy FH, Hassan MA (2008) Medicinal herb drying using a photovoltaic arrayed a solar thermal system. Solar Energy 82 (12):1154-1160

7. Andritsos N, Dalampakis P, Kolios N (2003) Use of geothermal energy for tomato drying. Geo Heat Cent Q 24(1):9-13

8. Kumoro AC, Kristanto D (2003) Preliminary study on the utilization of geothermal energy for drying of agricultural product. In: Proceedings of the international geothermal conference, September 2003, Reykjavik

9. Hirunlabh J, Thiebratand S, Khedari J (2004) Chili and garlic drying by using waste heat recovery from a geothermal power plant. GHC Bull (September)

10. Sumotarto U (2007) Design of a geothermal energy dryer for beans and grains drying in Kamojang geothermal field, Indonesia. Geo Heat Center Bull 28(1):13-18 
11. Dincer I, Sahin AZ (2004) A new model for thermodynamic analysis of a drying process. Int J Heat Mass Transfer 47(4):645-652

12. Akpinar EK, Midilli A, Bicer Y (2006) The first and second law analyses of thermodynamic of pumpkin drying process. J Food Eng 72:320-331

13. Akbulut A, Durmuş A (2010) Energy and exergy analyses of thin layer drying of mulberry in a forced solar dryer. Energy 35(4):1754-1763

14. Chowdhury MMI, Bala BK, Haque MA (2011) Energy and exergy analysis of the solar drying of jackfruit leather. Biosyst Eng 110(2):222-229

15. Midilli A, Kucuk H (2003) Energy and exergy analyses of solar drying process of pistachio. Energy 28(6):539-556

16. Colak N, Kuzgunkaya E, Hepbaşl $\iota$ A (2008) Exergetic assessment of drying of mint leaves in a heat pump dryer. J Food Process Eng 31(3):281-298

17. Kuzgunkaya EH, Hepbasli A (2007) Exergetic performance assessment of a ground source heat pump drying system. Int J Energy 31:760-777

18. Ozdiler U, Sayık T (2011) Balcova-Narlidere saha isletmesi. In: Jeotermal enerji semineri, Teskon, X. Ulusal Tesisat Mühendisliği Kongresi, Izmir, 13-16 April 2011

19. Cengel Y, Boles MA (2011) Thermodynamics: an engineering approach. McGraw-Hill, New York

20. Szargut J, Morris DR, Steward FR (1988) Exergy analysis of thermal, chemical and metallurgical processes. Hemisphere Publishing Corp, New York

21. Engineering Equation Solver (EES) (2012) Commercial and professional versions. F-Chart Software, Madison

22. Corzo O, Bracho N, Vasquezand A, Pereira A (2008) Energy and exergy analysis of thin layer drying of coroba slices. J Food Eng 86:151-161

23. Erbay Z, İçier F (2010) Energy and exergy analysis on drying of olive leaves (Oleaeuropaea L.) in tray drier. J Food Process Eng 34(6):2105-2123 